\title{
Ingen misdannelser av influensavaksine
}

\author{
Influensavaksine under svangerskapet øker ikke risikoen for medfødte \\ misdannelser hos barnet. Dette viser en studie fra Sverige.
}

Flere studier har vist varierende risiko for medfødte misdannelser hos barn der moren har fått influensavaksinen i første trimester,

men familiære forhold kan ha vært en konfunderende faktor som det ikke er tatt høyde for. I en nylig publisert studie fra Sverige har

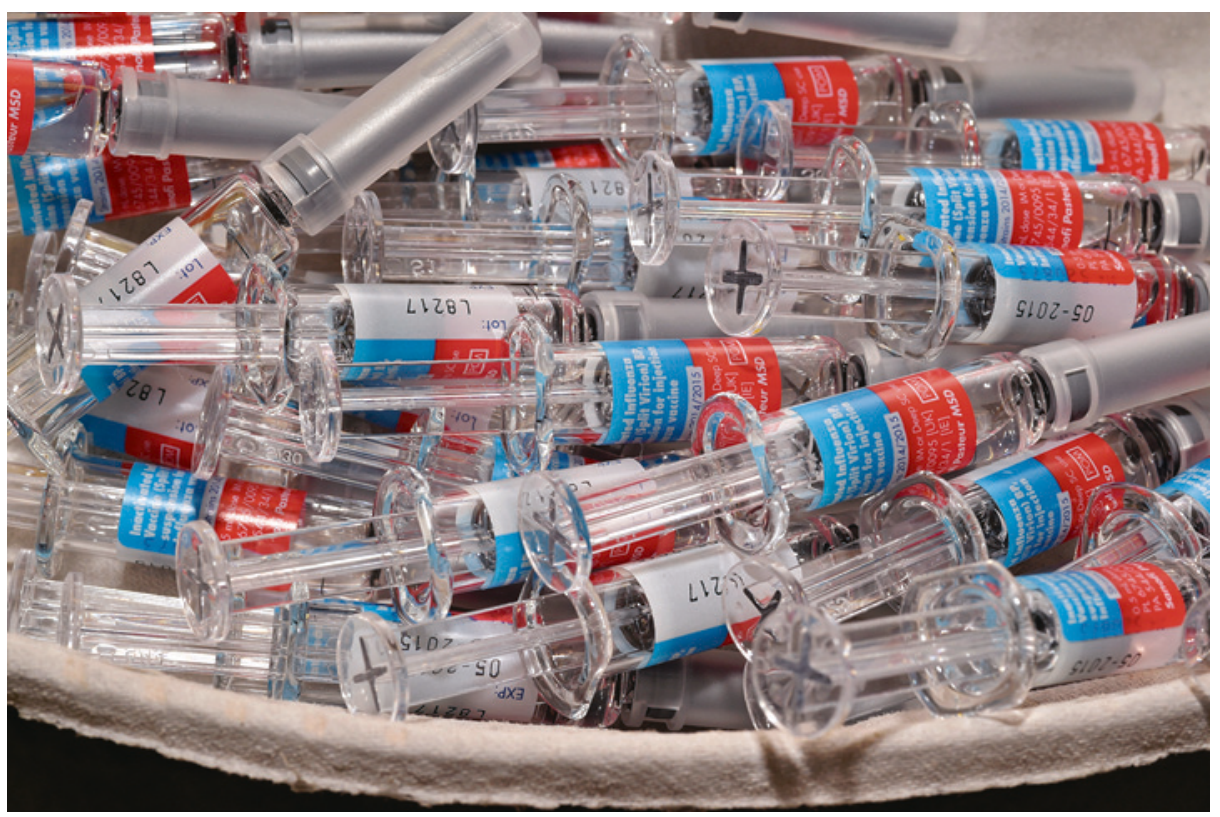

Ferdigfylte sprøyter og hetteglass som inneholder sesonginfluensavaksiner for 2014-15. Foto: Science Photo Library forskere sammenlignet søsken der moren fikk influensavaksine under ett av svangerskapene (1).

Studien omfattet flere enn 40000 barn der mor var blitt vaksinert i løpet av svangerskapet. Disse barna ble sammenlignet med rundt 200000 barn født i samme tidsperiode, der mor ikke var blitt vaksinert i løpet av svangerskapet, og med egne søsken.

Risikoen for misdannelser hos barn av vaksinerte mødre var omtrent lik i gruppene med og uten vaksinerte mødre. Forskjellen var på kun $0,02 \%$. Det var heller ingen signifikant økt risiko sammenlignet med søsken.

- Dette er en grundig studie av risikoen for medfødte misdannelser etter vaksinasjon med influensavaksinen som ble brukt $\mathrm{i}$ både Norge og Sverige under svineinfluensapandemien, sier Per Magnus, fagdirektør ved Folkehelseinstituttet.

- En av studiens styrker er søskendesignen, som innebærer kontroll for egenskaper ved familien. Dermed kan eksponerte barn sammenlignes med ikke-eksponerte søsken, sier Magnus.

\section{Kaveh Rashidi \\ Tidsskriftet}

\section{Litteratur}

1. Ludvigsson JF, Ström P, Lundholm C et al. Risk for congenital malformation with H1N1 influenza vaccine: a cohort study with sibling analysis. Ann Intern Med 2016; 165: 848-55.

\section{Vaksine produsert med syntetisk bioteknologi}

\section{Levende influensavaksine kan pro- duseres raskt og trygt med bruk av syntetisk bioteknologi.}

Ved produksjon av levende virusvaksiner bør vaksinens virulens være lavest mulig, samtidig som den ikke mister sin effekt. En ny studie viser at influensavaksiner kan produseres ved bruk av syntetisk bioteknologi (1).

Metoden tar utgangspunkt i en utvidet genetisk kode, der DNA-sekvensen som koder for viruset, ble modifisert med flere stoppsignaler som førte til at proteinproduksjonen i vanlige celler ble stoppet. I designede transgene celler ble det så satt inn et translasjonsmaskineri som kunne omdanne de induserte stoppsignalene til nye aminosyrer og dermed produsere protein
Vaksinen ble testet i mus, marsvin og ildere for å se at den modifiserte sekvensen ikke ble spontant reversert in vivo. Vaksinens immunrespons var sterkere sammenlignet med en tilgjengelig inaktiv vaksine. Det ble dessuten påvist antistoffer mot vaksinen i serum. Ved infeksjon med umodifisert influensavirus overlevde kun de musene som var vaksinert med den nye vaksinen.

- Levende virusvaksiner er effektive og sikre, men på grunn av faren for reversjon av patogenisitet er det en lang vei til godkjenning av levende vaksiner, sier Siri Mjaaland, som er forsker ved Folkehelseinstituttets avdeling for infeksjonsimmunologi, KB Jebsen Senter for influensavaksineforskning. - Dagens influensavaksiner er inaktiverte, multivalente subenhetsvaksiner som induserer antistoffer mot virusstammene i vaksinen. Utfordringen ligger i en kontinuerlig evolusjon av influensa- virusene som sirkulerer. Derfor er det viktig å velge korrekte stammer for bruk i vaksinene seks måneder før vaksinene skal brukes. Vaksiners effektivitet i praksis er langt fra optimal.

- Det drives nå intens forskning for å utvikle nye typer universelle influensavaksiner som kan indusere humorale og cellulære immunresponser mot et bredt spekter av virusstammer, der bruk av levende, svekkede virus i vaksinen er aktuell tilnærming, sier Mjaaland.

\section{Ruth Halsne}

Tidsskriftet

\section{Litteratur}

1. Si L, Xu H, Zhou X et al. Generation of influenza A viruses as live but replication-incompetent virus vaccines. Science 2016; 354: 1170-3 